\title{
DETERMINING BUSINESS EVENT LEGACIES BEYOND THE TOURISM SPEND: AN AUSTRALIAN CASE STUDY APPROACH
}

\author{
CARMEL FOLEY, $*$ KATIE SCHLENKER, ${ }^{*}$ DEBORAH EDWARDS, $*$ AND LYN LEWIS-SMITH $\dagger$ \\ *UTS Business School, University of Technology Sydney, Sydney, Australia \\ $\dagger$ Business Events Sydney, Sydney, Australia
}

\begin{abstract}
Government and industry are aware that the full value of the business event sector needs to be established. To date, the sector has been evaluated on the economic contribution it makes to host destination tourism. The tourism contributions have been impressive in themselves; however, this narrow focus has failed to account for a more extensive set of contributions to economies and communities. Impacts from business events in areas such as innovation, education, networking, trade, research, and practice are generally considered to outweigh the financial returns of the tourism spend. Although anecdotal evidence of the value of business events beyond the tourism dimension has been evident for some time, empirical research in this area is limited. This article has four objectives: first, to highlight the research need for understanding the broader impacts of business events beyond the tourism spend; second, to identify the range and impact of contributions made by business events to host communities beyond the tourism spend; third, to examine five Australian business events utilizing a grounded theory approach and present a range of identified legacies in the categories of knowledge expansion; networking, relationships, and collaboration; educational outcomes; raising awareness and profiling; and showcasing and destination reputation. Finally, the article discusses the implications of these findings for the business events sector.
\end{abstract}

Key words: Business events; Legacy; Collaboration; Networking; Knowledge; Relationships

\section{Introduction}

Business tourism is concerned with people traveling for purposes that are related to their work (Davidson, 1994). Some of these purposes include inter alia attendance at meetings, incentives, conferences, exhibitions, conventions, and trade fairs (collectively referred to as MICE), increasing the sales of products and services, training and research that is related to employment or products, and building the customer base. The term "business events" is increasingly being used by academics and industry to refer to MICE activities (Mair \& Jago, 2010; Tourism Research Australia, 2009). 
Business events has been defined as "a collective term referring to association conventions, corporate and government meetings, exhibitions, and incentive travel reward programs" (The Business Events Industry Strategy Group, 2008, p. i).

Business event travelers are high-yield visitors. In Australia, in 2011 they spent an average \$248 per night compared with $\$ 135$ per night for the average traveler (Tourism Research Australia, 2012). In 2011, 19.2 million international and domestic business event visitors spent 40.5 million visitor nights in Australia, which generated $\$ 10$ billion in expenditure (Tourism Research Australia, 2012). As these figures indicate, the business event sector contributes significantly to Australia's tourism industry and has been aptly described as a "seam of gold" running through Australian tourism (Carlsen, 1995; Jago \& Deery, 2010). It is not surprising then that the measures used to assess the value of the business event sector have focused almost exclusively on this economic contribution to host destination tourism, referred to in this article as the tourism spend.

To address the need to understand the benefits of business events beyond the tourism spend, there has been a flurry of simultaneous activity with a small number of studies beginning to explore the broader value of business events, using a range of methods commissioned by Australian agencies working in the business event sector (Business Events Council of Australia, 2009a, 2009b, 2010; Edwards, Foley, \& Schlenker, 2011; Foley, Schlenker, \& Edwards, 2011; Jago \& Deery, 2010, 2011; The Business Events Industry Strategy Group, 2008). This article presents the findings of a study that examined the beyond-tourism benefits of business events using a grounded theory approach. This approach allowed the researchers to develop a theoretical account of the legacies of business events while simultaneously grounding the account in empirical observations of the data collected for five exploratory case studies.

\section{Literature Review}

Business events are well established as valuable investments by national governments in the economic development of their countries. As a result, there is a strong understanding of the economic impact of business events in terms of tourism spend for which historically they demonstrate solid economic benefits (see Business Events Council of Australia, 2009a, 2009b; Jago \& Deery, 2010; The Business Events Industry Strategy Group, 2008). The implicit connection between the tourism industry and business events has led to the value of business events being largely determined by directly measurable, economic benefits that relate, almost exclusively, to the tourism industry. The merit of business events is often measured, for example, by visitor numbers, daily expenditure, nights spent away, and other economic contributions by visitors to the event destination (Tourism Research Australia, 2009, 2010).

Business event attendees have been known to have higher daily expenditure and longer duration of stay compared to all other tourists (Carlsen, 1995), resulting in the business event delegate being "widely regarded as the most desirable visitor in the world" (Business Events Council of Australia, 2009 b, p. 2). There is a growing recognition, however, that the value of business events extends well beyond the tourism spend and that a business event should not be measured merely by its direct financial contribution (Dwyer, Mellor, Mistilis, \& Mules, 2000). Swarbrooke and Horner (2001) argue that the social impacts arising from business events could be considered as providing jobs, supporting infrastructure and facilities, bringing new ideas to the local community, and motivating employees and business travelers. However, they qualify these broader outcomes by stating that the social impacts were highly dependent "on the volume of conferences in a particular destination" (Swarbrooke \& Horner, 2001, p. 82). That is, the outcomes were high in major convention destinations and limited for exhibitions that failed to attract large numbers of exhibition visitors.

For multiple reasons, it is crucial that the broader value of business events be recognized. The business event sector requires support from governmentsparticularly in the areas of infrastructure development and global marketing. In Australia, the sector is continually being called upon to demonstrate its full value to governments in order to attract and maintain adequate funding and support (Business Events Council of Australia, 2009b). A focus on tourism spend inevitably leads to continual demands for increased monetary outcomes that in the long 
term are unsustainable. An improved understanding of the broader contributions to be made by business events can inform the development of strategies to maximize a broader range of event benefits for the host destination. Destination management and marketing organizations require knowledge to inform marketing and strategic planning so that a destination can maximize opportunities for maintaining strong domestic markets and growing their share of a highly competitive global market (Business Events Council of Australia, 2009b).

Such strategies would be particularly timely given the current status of the Australian business event industry. Australia's international business events performance has been decreasing in recent years, and Australia has been losing market share (Business Events Council of Australia, 2010). This drop in the current market led to a call for actions to strengthen the industry's position and profile.

Whereas the tourism and economic contributions are significant, the impacts from business events beyond the tourism spend are receiving greater attention (Business Events Council of Australia, 2009b). Although anecdotal evidence of the value of business events beyond the tourism dimension has been apparent for some time, research in this area has been minimal. One reason for this is the complexity and nuances involved in measuring the broader contributions of business events (Wood, 2009). Consequently, what is known about the broader benefits of business events is limited, often resulting in a lack of accurate, meaningful, empirical data that are useful.

The purpose of this study is to examine the range and impact of contributions made by business events to host communities beyond the tourism spend with a focus on business events held in Sydney, Australia, using grounded theory as a methodological approach. Grounded theory's strong assertion is that a literature review in the substantive area is not undertaken until the sorting and writing up of the grounded theory, at which time the literature can be used for comparison (Glaser, 1998).

\section{Methodology}

Due to the lack of empirical data used in previous research on the benefits of business events beyond the tourism spend, it was decided to use grounded theory as the methodology to analyze data from exploratory case studies (Fernandez, 2005). Grounded theory is a well-recognized way to research a little studied area (Denzin \& Lincoln, 2003). Grounded theory is an approach in which the analyst becomes increasingly "grounded" in the data and develops richer concepts and models of how a phenomenon really works (Denzin \& Lincoln, 2003). Two key elements underpin grounded theory: "(a) the researcher has to set aside theoretical ideas, and (b) the concepts are developed through constant comparison" (Fernandez, 2005, p. 45). Rather than proving or disproving theory, the researcher identifies potential themes by pulling together real examples from the data and constantly comparing relationships among themes. Grounded theory is a general method of analysis that accepts qualitative, quantitative, and hybrid data collection from surveys, experiments, and case studies (Glaser, 1978, 1998). Using it as an overarching methodology to analyze data from five exploratory case studies assisted the researchers in studying the phenomenon in a natural setting and generating theories from practice.

\section{The Case Studies}

To meet the methodological demands of the project, a case study approach was adopted for the inquiry. The case study approach provides the researcher with flexibility to situate people, organizations, events, and experiences in their social and historical context and to treat the subject of the study as a whole rather than abstracting a limited set of preselected features (Veal, 2006). This allowed the complexities and fine distinctions of each case to be taken into account while the overall benefits derived from the business event are investigated.

Case study investigations can involve single or multiple cases (Veal, 2006). Although there is no "required" number of cases, consideration was given to the research context and resources available. Five cases were selected for this study. The cases were drawn from Business Events Sydney's list of bid wins and were selected on the basis of two criteria. First, selection was made on the basis of the year in which the conference was held in order to compare and contrast the timeline effect of "legacy" delivery. Case studies were selected from business events held in each year of the period 2007-2010 inclusive. Second, conferences were drawn from a cross section 
Table 1

Case Studies

\begin{tabular}{lll}
\hline Business Event & \multicolumn{1}{c}{ Date Held } & \multicolumn{1}{c}{ Sector } \\
\hline $\begin{array}{l}\text { 4th International AIDS Society } \\
\quad \begin{array}{l}\text { Conference on HIV Pathogenesis, } \\
\text { Treatment and Prevention (IAS 2007) }\end{array}\end{array}$ & July 22-25, 2007 & Medical \\
$\begin{array}{l}\text { 3rd Asia Pacific Regional International } \\
\quad \text { Solar Energy Society Conference } \\
\text { (ISES 2008) }\end{array}$ & November 25-28, 2008 & Ecology/environment \\
$\begin{array}{l}\text { 19th World Congress of the ISLSSL } \\
\text { (ISLSSL 2009) }\end{array}$ & September 1-4, 2009 & Law \\
$\begin{array}{l}\text { 7th International Orthodontics Congress } \\
\text { (IOC 2010) }\end{array}$ & February 6-9, 2010 & Medical \\
$\begin{array}{l}\text { 5th IWG World Conference on Women } \\
\text { and Sport (IWG 2010) }\end{array}$ & May 20-23, 2010 & Sport/gender \\
\hline
\end{tabular}

of sector types to permit analysis of a reasonable breadth of business event contributions across different sectors. Table 1 presents the names, dates, and sector types of the cases used in the study. Each business event potentially produces a unique set of outcomes, and the five cases provided the opportunity to compare and gain information on a variety of business event outcomes.

Data for the case studies were collected during May/June 2010 using in-depth interviews and secondary data analysis. The interviews were as broad as possible and did not include a priori constructs or guiding theories. Interview participants were selected using a purposive sampling technique designed to select "information-rich" respondents who have the specific knowledge the researcher is looking for (Mertens, 2005). Interviews were thus held with key representatives of the organizations responsible for hosting each of the five selected business events. Further interview respondents were accessed through the use of snowball sampling. Use of this method resulted in the researchers gaining access to a wide spectrum of further interviewees, including association members, event delegates, sponsors, and exhibitors. Interviews were held with these additional event stakeholders to confirm initial claims and to gather additional data on business event outcomes. All interviews were transcribed, and texts were produced for analysis. In addition to the interview data, secondary data, in the form of event and industry information, including event evaluation reports, were collected and analyzed.

The researchers wrote theoretical memos in parallel with the interviews. Theoretical memos are "the theorising write-up of ideas about codes and their relationships as they strike the analyst while coding" (Glaser, 1978, p. 83). It is important to produce memos in grounded theory from the beginning until the end, as they assist in establishing relationships between codes that are grounded in the data (Heath \& Cowley, 2004). As patterns emerged and the data were reduced to one or two core themes, these themes became guides for further data collection and analysis (Glaser, 1978). It was at this stage that the extant literature became important as a source of more data to compare with the case study data.

Literature on industry reports about the intangible benefits of business events relevant to this study were reviewed (see Business Events Council of Australia, 2009a, 2009b, 2010; Jago \& Deery, 2010, 2011; Joint Meetings Industry Council, 2008; The Business Events Industry Strategy Group, 2008). These reports indicated that the potential intangible benefits of business events may include knowledge expansion, community "outcomes," innovation and collaborative projects, international relations, trade opportunities, networking opportunities, education, and enhanced business-to-business relationships. During round table discussions the researchers integrated the themes with the developing theory. In this process, the literature findings were applied to the data and further reviewed, allowing new themes to evolve. Where points of difference arose, the original data were reviewed and revised until there was agreement on thematic development. Grounded theory is an appropriate approach to use when the researcher has professional experience in 
the substantive area of study because it provides a method to deal with researcher experience, controlling the risk of introducing bias into the study (Fernandez, 2005; Glaser, 1998). This control was achieved by the constant comparative method. The researchers included their assumptions and their own knowledge as data (in the form of memos and self-interviews) and compared these data with other data from the study. The constant comparison of data validates, modifies, or rejects the researchers' observations, thus reducing the risk of bias-induced distortions (Fernandez, 2005).

\section{Findings}

Through the analysis, six core themes emerged and reflect the benefits and outcomes that can arise from a business event. They are knowledge expansion, networking, relationships and collaboration, fundraising and future research capacity, raising awareness and profiling, and showcasing and destination reputation. Table 2 indicates how each code contributes to the core themes. As evident in Table 2 some codes are relevant to more than one theme.

\section{Knowledge Expansion}

Business events facilitate the dissemination of new knowledge, techniques, and technologies. This contributes not only to capacity building within a specific sector, but also to improved educational offerings and professional practice in the sector. This theme was derived from the codes growing local knowledge, knowledge improving education, and knowledge improving professional practice. The general findings as they relate to each code are presented here together with some examples and illustrative quotes from the case study data.

\section{Growing Local Knowledge}

Business events represent an opportunity to bring the world's best practice and international knowledge to members of the local sector. In the case of the International Society for Labour and Social Security Law (ISLSSL) 2009 conference, "bringing people together from around the world to meet in Australia plays an important role in growing Australian knowledge" (ISLSSL 2009 host organization representative). Growing local knowledge in turn contributes to capacity building within the relevant sector in the host destination. The business event plays an important role as "the majority of practitioners acquire their knowledge base from meetings" [International Orthodontics Congress (IOC) 2010 host organization representative].

\section{Knowledge Improving Education}

Business events expose delegates to new knowledge and ideas, which within a reasonably short time frame can be incorporated into current educational offerings. This improves the quality of education in the field, which has flow-on benefits for the quality of graduates who work in the sector after their studies. ISLSSL 2009 was considered to provide delegates with "access to cutting-edge research in the areas of labor and social security law. Academics attending this conference can incorporate this new knowledge into course content at tertiary education institutions across Australia" (ISLSSL 2009 host organization representative).

\section{Knowledge Improving Professional Practice}

New knowledge, techniques, and technologies shared at a business event are also used for improving professional practice in the relevant sector. This transfer of knowledge has implications for the local community, evidenced in the implementation of new knowledge, techniques, or materials into professional practice in the relevant sector. IOC 2010 provides a clear example of knowledge improving professional practice, as "clinicians can place orders at the congress for new materials and implement new techniques into their practice within a month" (IOC 2010 host organization representative). Another example is the reported changes to clinical practice as a result of attending IAS 2007, including the use of new drugs or technologies in treating patients with HIV (International AIDS Society, 2009).

\section{Networking, Relationships, and Collaboration}

Face-to-face networking between individuals and groups at a business event leads to the benefits of networking, relationship building, and collaboration that have the potential to generate innovation, 
Table 2

Codes and Coding Themes

\begin{tabular}{|c|c|c|c|c|c|c|}
\hline \multirow[b]{2}{*}{ Codes } & \multicolumn{6}{|c|}{ Coding Themes } \\
\hline & $\begin{array}{l}\text { Knowledge } \\
\text { Expansion }\end{array}$ & $\begin{array}{l}\text { Networking, } \\
\text { Relationships } \\
\text { and } \\
\text { Collaboration }\end{array}$ & $\begin{array}{c}\text { Educational } \\
\text { Outcomes }\end{array}$ & $\begin{array}{l}\text { Fundraising } \\
\text { and Future } \\
\text { Research } \\
\text { Capacity }\end{array}$ & $\begin{array}{l}\text { Raising } \\
\text { Awareness } \\
\text { and } \\
\text { Profiling }\end{array}$ & $\begin{array}{c}\text { Showcasing } \\
\text { and } \\
\text { Destination } \\
\text { Reputation }\end{array}$ \\
\hline 1. Growing local knowledge & $\mathrm{X}$ & & & & & \\
\hline 2. Knowledge improving education & $\mathrm{X}$ & & $X$ & & & \\
\hline $\begin{array}{l}\text { 3. Knowledge improving } \\
\text { professional practice }\end{array}$ & $\mathrm{X}$ & & & & & \\
\hline $\begin{array}{l}\text { 4. Access to networking opportuni- } \\
\text { ties for local practitioners and } \\
\text { researchers }\end{array}$ & & $\mathrm{X}$ & & & & \\
\hline $\begin{array}{l}\text { 5. Networking fosters creation of } \\
\text { long-term relationships }\end{array}$ & & $\mathrm{X}$ & & & & \\
\hline $\begin{array}{l}\text { 6. Networking as a catalyst for } \\
\text { knowledge expansion and } \\
\text { research development }\end{array}$ & $\mathrm{X}$ & $\mathrm{X}$ & & & & \\
\hline $\begin{array}{l}\text { 7. Networking as a catalyst for } \\
\text { research collaborations }\end{array}$ & & $\mathrm{X}$ & & $\mathrm{X}$ & & \\
\hline $\begin{array}{l}\text { 8. Research collaborations lead to } \\
\text { development of new products } \\
\text { and technologies }\end{array}$ & & $\mathrm{X}$ & & & & \\
\hline $\begin{array}{l}\text { 9. Opportunities for local post- } \\
\text { graduate research students }\end{array}$ & & & $\mathrm{X}$ & & & \\
\hline $\begin{array}{l}\text { 10. Increased attractiveness of } \\
\text { education sector }\end{array}$ & & & $\mathrm{X}$ & & & \\
\hline 11. Fundraising opportunities & & & & $\mathrm{X}$ & & \\
\hline $\begin{array}{l}\text { 12. Greater access to government } \\
\text { and/or private sector funding } \\
\text { sources }\end{array}$ & & & & $\mathrm{X}$ & & \\
\hline $\begin{array}{l}\text { 13. Generating awareness of sector- } \\
\text { specific issues }\end{array}$ & & & & & $\mathrm{X}$ & \\
\hline $\begin{array}{l}\text { 14. Raising awareness of broader } \\
\text { societal issues }\end{array}$ & & & & & $\mathrm{X}$ & \\
\hline $\begin{array}{l}\text { 15. Profiling local organizations, } \\
\text { associations, and/or centers }\end{array}$ & & & & & $\mathrm{X}$ & $\mathrm{X}$ \\
\hline $\begin{array}{l}\text { 16. A catalyst for government } \\
\text { support }\end{array}$ & & & & & $\mathrm{X}$ & \\
\hline 17. Showcasing local talent & & & & & $\mathrm{X}$ & $\mathrm{X}$ \\
\hline $\begin{array}{l}\text { 18. Enhancing Sydney's reputation } \\
\text { as a global leader }\end{array}$ & & & & & & $\mathrm{X}$ \\
\hline $\begin{array}{l}\text { 19. Enhancing Sydney's reputation } \\
\text { as a business events destination }\end{array}$ & & & & & & $\mathrm{X}$ \\
\hline
\end{tabular}

$\mathrm{X}$, code is central to core category.

ideas, and research agendas for years to come. This theme was derived from the codes access to networking opportunities for local practitioners and researchers; networking fosters creation of longterm relationships; networking as a catalyst for knowledge expansion and research development; networking as a catalyst for research collaborations; and research collaborations lead to development of new products and technologies. The general findings as they relate to each code are presented here together with some examples and illustrative quotes from the case study data.

\section{Access to Networking Opportunities for Local Practitioners and Researchers}

Business events provide local practitioners and researchers the opportunity to network with 
international counterparts within a specific sector. This is considered particularly important for members of the host destination who are able to attend a local event, but who may otherwise not be able to access international colleagues. For example, in the case of ISLSSL 2009, "the Sydney location was considered important for both academics and practitioners who may not have the opportunities to travel to international conferences to meet with others working in the field" (ISLSSL 2009 host organization representative). Being able to access networking opportunities in the host destination is also important for more junior members of a field, as the following quote illustrates. "The high profile researchers within the centre attend many international conferences; however, the clinical staff and junior researchers don't have the same opportunity so being staged in Sydney gave them the opportunity to attend and subsequently meet highprofile international delegates" (IAS 2007 National Research Centre representative).

\section{Networking Fosters Creation of \\ Long-Term Relationships}

Business events foster networking by physically bringing people together to share new knowledge and ideas and spark potential relationships. The networking that takes place at business events represents a benefit that continues to be felt long after the event has ended, as the following example demonstrates. "Although delegates may have met back in 2007, that face-to-face meeting and networking that took place at the conference allows people to feel that they can still contact them, having shared that conference experience a few years back" (IAS 2007 local host organization representative). Thus, it is the face-to-face meeting that is considered important in strengthening a long-term relationship.

Networking is also important for the creation of business relationships. An Australian company specializing in heat engine generator technology was a sponsor, exhibitor, and presenter at the International Solar Energy Society (ISES) 2008 conference. It was reported that they gained exposure and networking opportunities, which resulted in the establishment of long-term business relationships from contacts made at the conference (ISES 2008 exhibitor interview).

\section{Networking as a Catalyst for Knowledge Expansion and Research Development}

The networking that takes place at business events acts as a catalyst for knowledge expansion and can result in generation of ideas that drive future research agendas. For example, at IAS 2007 "one of the big discussion points was about circumcision in Africa leading to marginally lower rates of HIV infection in heterosexuals - the question became, is this the same in the Australian community. Subsequently a study has been conducted to explore this issue" (IAS 2007 National Research Centre representative).

\section{Networking as a Catalyst for Research Collaborations}

Networking acts as a catalyst for developing research collaborations, particularly among academics. People who meet at the conference and find they are working on studies in the same area may decide to collaborate in the future. For example, it was reported that International Working Group (IWG) 2010 contributed to developing networks among practitioners in the field and research collaborations among academics (IWG 2010 organizing committee representative). Similarly, the networking that took place at ISLSSL 2009 was said to result in "various research groups that have sprung up. I have no doubt there are other research projects going on, not just from people in Australia but other people from different countries who met in Sydney and got together" (ISLSSL 2009 host organization representative).

\section{Research Collaborations Lead to Development of New Products and Technologies}

Collaborations formed through the networking opportunities provided by business events can have further outcomes evidenced in the development of new products and technologies. This outcome was achieved as a result of ISES 2008, where "as a result of the conference, collaboration has occurred 
that is resulting in the creation of integrated affordable building products" (ISES 2008 host organization representative).

\section{Educational Outcomes}

Educational outcomes highlight the varied opportunities afforded the local education sector as a result of hosting a business event. This theme was derived from the codes opportunities for local postgraduate research students and increased attractiveness of education sector. The general findings as they relate to each code are presented together with some examples and illustrative quotes from the case study data.

\section{Opportunities for Local Postgraduate Research Students}

Attendance at a business event delivers opportunities that are considered important in building the young people working in a sector, including early career researchers and practitioners, local postgraduate research students, and emerging leaders in the sector. IWG 2010, for example, was reported to have provided local postgraduate students with vital contacts for future research opportunities (IWG 2010 organizing committee representative).

Another outcome that is significant for early career academics or practitioners and students is the opportunity to gain validation and enthusiasm for their chosen career path through meeting leaders in their field. A business event provides the opportunity for such interaction that can provide the impetus for "people to go away and be enthused about what they are doing locally. It can build their passion or their interest in the area" (IAS 2007 local host organization representative).

\section{Increased Attractiveness of Education Sector}

In addition to the benefits provided to individual members of the local education sector, a business event also provides positive outcomes in terms of increasing the attractiveness of the education sector as a whole.

By exposing delegates to local knowledge, research capacity, sites, and facilities, business events can create flow on effects in terms of increasing the attractiveness of the destination's education sector. This can lead to tangible benefits such as those described in the following quote. "I know individuals [who have attended Australian conferences from other countries] who have come back as students. Students want to be where a place is pushing the barriers. Our conference demonstrated that we are pushing the barriers in Australia" (ISES 2008 host organization representative). Such growth in the education sector also has wider benefits for increasing the future capacity of the relevant sector.

\section{Fundraising and Future Research Capacity}

Fundraising and future research capacity reflects the opportunities available to local organizations, associations, and/or centers involved with a business event. These entities, through the event, have increased access to additional sources of funds, which in turn can have implications for the sector in terms of growing future research capacity. This theme was derived from the codes fundraising opportunities and greater access to Government and/or private sector funding sources. The general findings, as they relate to each code, are presented together with some examples and illustrative quotes from the case study data.

\section{Fundraising Opportunities}

Business events provide opportunities for local organizations, associations, and/or centers involved with the event to raise funds. A positive outcome of the IOC 2010 was a significant increase in funds for the Foundation for Research and Education, established by the Australian Society of Orthodontists to promote and advance orthodontic research and education in Australia. This funding boost will support more and larger projects to be undertaken by Australian researchers (IOC 2010 host organization representative).

\section{Greater Access to Government and/or Private Sector Funding Sources}

Business events deliver opportunities for accessing greater funding support from Government and the private sector, which can have implications for the sector in terms of growing future research capacity. 
One example from IAS 2007 was the receipt of a grant of US\$18 million from the Bill and Melinda Gates Institute, matched by Commonwealth funding. The grant funded the establishment of a major virology institute in New South Wales focusing on transmitted diseases such as HIV, AIDS, TB, and hepatitis (Business Events Sydney, 2009).

Another example is the $\$ 10,000$ seed funding for the "Sydney Scoreboard" provided by the Greater Sydney Partnership (GSP) as part of IWG 2010. The Sydney Scoreboard initiative is designed to monitor global progress regarding women in sport governance until at least 2014. To achieve this aim, research collaborations have already begun among delegates from Australia, Tunisia, Botswana, US, New Zealand, and Canada (IWG 2010 organizing committee representative).

\section{Raising Awareness and Profiling}

The media coverage associated with many business events not only can raise the profile of associated organizations, but also can raise awareness of significant issues from within a sector. This theme was derived from the codes generating awareness of sector specific issues; raising awareness of broader societal issues; profiling local organizations, associations, and/or centers; and a catalyst for government support. The general findings as they relate to each code are presented together with some examples and illustrative quotes from the case study data.

\section{Generating Awareness of Sector Specific Issues}

Business events are capable of raising both public and government awareness of sector specific issues. This outcome is often realized through the media coverage afforded to certain business events, which may have high-profile speakers or support. International media coverage can ensure that this message is taken to an even wider audience than the host destination.

IAS 2007, for example, secured "a lot of media locally, Asia Pacific, and internationally around the event. If that serves to put HIV at the forefront of people's minds - public, government and others, then that could have benefits" (IAS 2007 local host organization representative).
Local and international media coverage of IWG 2010 helped raise awareness of the issues associated with women and sport, in part due to the involvement in the event of influential and high-profile speakers including former High Court judge Michael Kirby, then Federal Minister for Sport Kate Ellis, and prominent Sydney businessman Peter Holmes à Court (IWG 2010 organizing committee representative).

\section{Raising Awareness of Broader Societal Issues}

Business events can be used to raise awareness of broader social issues. Such efforts to address broader social issues can reflect positively on the reputation of the host destination as a site capable of driving action and social change. For example, ISLSSL 2009 was used to address issues of gender inequality. 'I'm very concerned about conferences I go to in Europe in the Law areas where most of the speakers are men. I wanted a woman to give the keynote address. . . . I think that was important giving her . . . a number one role" (ISLSSL 2009 host organization representative).

\section{Profiling Local Organizations, Associations, and/or Centers}

Business events provide opportunities to raise the profile of local organizations, associations, and/ or centers involved with the event. For example, to coincide with IAS 2007, the National Centre in HIV Epidemiology and Clinical Research took the opportunity to celebrate the organization's 20th anniversary. "They had 1,200 national and international delegates attend the anniversary celebrations - which they were absolutely thrilled about. It increased their profile and enhanced the national and international awareness of the center" (IAS 2007 National Research Centre representative).

\section{A Catalyst for Government Support}

The media attention and increased public and private sector awareness of the issues central to a business event can prompt expressions of support from government, in the form of increased funding or revised public policy outcomes. For example, in his keynote address at ISES 2008, The Hon Peter 
Garrett AM, Federal Minister for Environment Protection, Heritage and the Arts, announced the largest ever Commonwealth investment in solar power.

Similarly, in her keynote address at the IWG conference, The Hon Kate Ellis MP, then Federal Minister for Sport, announced that "the Australian government will require all national sporting organizations to annually report on the gender representation of their boards."

\section{Showcasing and Destination Reputation}

A business event can showcase not only the local talent working in a specific field but also the capability of the destination itself as a business events destination. This theme was derived from the codes showcasing local talent, enhancing Sydney's reputation as a global leader, and enhancing Sydney's reputation as a business events destination. The findings as they relate to each code are presented together with some examples and illustrative quotes from the case study data.

\section{Showcasing Local Talent}

The hosting of a business event in Sydney has beneficial outcomes in terms of showcasing local talent in a specific sector. For example, IOC 2010 was successful in showcasing Australian research to a global audience as well as providing emerging Australian academics with exposure and status within the international orthodontic community (IOC 2010 host organization representative). Similarly, IAS 2007 was considered important in raising awareness of the research and scientific excellence of those working in the Australian HIV sector to international delegates (IAS 2007 local host organization representative).

\section{Enhancing Sydney's Reputation as a Global Leader}

By showcasing local talent, a business event can put a destination "on the map," fostering a reputation as a place of highly skilled, capable, world leading researchers, educators, and practitioners in a specific sector.
Professor David Cooper of the National Centre in HIV Epidemiology and Clinical Research at the University of South Wales was the IAS 2007 conference co-chair. He has previously been quoted as saying "being the successful bidder for the IAS scientific conference reinforced to the international HIV research community the value of the work done in Australia. We bat a long way above our weight in this field" (Cooper cited in Business Events Sydney, 2009).

Another example is ISLSSL 2009, which provided positive outcomes for "putting Australia on the map" in the subdiscipline of labor and social security law with a group of people from around the world (ISLSSL 2009 host organization representative).

\section{Enhancing Sydney's Reputation as a Business Events Destination}

Successful hosting of a business event is important in itself for enhancing Sydney's reputation as a business events destination. For example, attracting over 6,000 delegates to Sydney, IAS 2007 was considered "a good meeting to have had here to say we won this and we can hold this sort of meeting" (IAS 2007 local host organization representative).

Sydney's capability as a business events destination is also strengthened through continued hosting of business events, as the sector develops along with the skills of those working within it. Hosting of IAS 2007 in Sydney was thought to represent a "benefit for future conferences held here [Sydney] and people's skills in working on something like that" (IAS 2007 local host organization representative).

\section{Implications and Conclusion}

It is well established that business events make a substantial contribution to the Australian economy from a tourism perspective. However, there have been significant gaps in our understanding of the full value of business events. By developing business event profiles outside of the traditional tourism parameters, a move toward a more extensive understanding of business events and their contributions has been achieved. Although the value of the tourism spend remains crucial, the broader contributions 
of business events arguably have more value than the tourism dollar for a number of reasons. They bring best practice and international knowledge to local sector researchers and practitioners in the fields of medicine, law, sport, and the environment. It is knowledge that contributes to capacity building within each sector, is incorporated into educational offerings, improves the quality of education in the various sectors, and has flow-on benefits for the quality of graduates who enter the field after their studies. Importantly, practitioners are able to implement new practices immediately after the event, whereas networking at business events provides local delegates with new business and research collaborations that generate innovation, ideas, and research agendas for many years to come.

The events have provided Sydney organizations, associations, and research centers with new funding from both the Federal Government and the private sector: a critical outcome that assists in driving growth in the research capacity of each sector. Enhancing Sydney's reputation as a business events destination has the long-term benefit of positioning Sydney for future business events.

This study has established that the benefits derived from business events extend well beyond economic contributions to tourism. Evidence presented in this article verifies the contributions of five business events held in Sydney in the period 2007-2010 in areas of knowledge expansion; networking, relationships, and collaboration; educational outcomes; fundraising and future research capacity; raising awareness and profiling; and showcasing and destination reputation.

A more extensive understanding of business events and their contributions provides important ammunition for the sector in attracting and maintaining adequate government funding and support for business events. Evidence-based confirmation of the value of business events (economic and otherwise) will allow the business events sector to more effectively communicate with politicians, the media, and the business community to provide a strong, consistent, and clear message of the positive impact of business events beyond the direct tourism spend (Business Events Council of Australia, 2009a). This could potentially result in greater government investment in the sector, playing an important role in strengthening the industry's position and profile in a highly competitive global market.

Understanding of the broader contributions to be made by business events also has value for the organizers of business events. A greater appreciation for the potential of business events could result in the development of strategies to maximize the benefits to be realized from their hosting. This could also lead to an improved incorporation of such benefits into the branding and marketing strategies for business events.

This study provides baseline evidence that confirms the benefits derived from business events do extend beyond the tourism contribution. Although the scope and range of these broader contributions have been identified, the extent of these benefits remains unknown. The findings in this study, based on a sound qualitative methodological approach, would benefit from being rounded out by further studies based on a quantitative approach. As such, further research is currently under way to deliver a quantitative assessment of the impact of the range of contributions made by business events to host communities beyond the tourism spend.

\section{Acknowledgment}

The authors would like to thank Business Events Sydney for supporting this research.

\section{References}

Business Events Council of Australia. (2009a). Business events summit-Post summit report. Retrieved December 4, 2011, from http://www.businesseventscouncil.org. au/files/be summit 09 final report.pdf

Business Events Council of Australia. (2009b). Business Events Council of Australia (BECA) pre-budget submission to the Federal Government. Retrieved December 4, 2011, from http://www.businesseventscouncil.org.au/ files/beca pbs feb_09.pdf

Business Events Council of Australia. (2010). Business Events Council of Australia (BECA) pre-budget submission to the Federal Government 2010-11. Business Events Council of Australia. Retrieved December 4, 2011, from http://www.businesseventscouncil.org.au/files/beca pbs 2010.pdf

Business Events Sydney. (2009). Congress outcomes. Sydney: Burson Marsteller.

Carlsen, J. (1995). Gathering information: Meetings and conventions sector research in Australia. The Journal of Tourism Studies, 6(2), 21-29. 
Davidson, R. (1994). Business travel. Harlow, UK: Addison Wesley Longman.

Denzin, N. K., \& Lincoln, Y. S. (Eds.). (2003). Strategies of qualitative inquiry (2nd ed.). Thousand Oaks, CA: Sage.

Dwyer, L., Mellor, R., Mistilis, N., \& Mules, T. (2000). A framework for assessing "tangible" and "intangible" impacts of events and conventions. Event Management, 6(3), 175-189.

Edwards, D., Foley, C., \& Schlenker, K. (2011). Beyond tourism benefits: Measuring the social legacies of business events. Retreived December 4, 2011, from http:// www.businesseventssydney.com.au/fms/About\%20us/ Publications\%20and\%20resources/Documents/Beyond\% 20 Tourism $\% 20$ Benefits $\% 20$ Measuring $\% 20$ the $\%$ 20 social $\% 20$ legacy $\% 20$ of $\% 20$ business $\% 20$ events.pdf

Fernandez, W. D. (2005). The grounded theory method and case study data in IS research: Issues and design. In D. Hart \& S. Gregor (Eds.), Information systems foundations constructing and criticising. Paper presented at the Information Systems Foundations Workshop: Constructing and Criticising, Canberra, Australia. Canberra: ANU E Press.

Foley, C., Schlenker, K., \& Edwards, D. (2011). A scoping study of business events: Beyond tourism benefits. Retreived December 4, 2011, from http://www. businesseventssydney.com.au/fms/Latest \%20news/ Beyond\%20Tourism\%20Benefits\%20-\%20Final\%20 Report.pdf

Glaser, B. G. (1978). Theoretical sensitivity. Mill Valley, CA: Sociology Press.

Glaser, B. G. (1998). Doing grounded theory: Issues and discussion. Mill Valley, CA: Sociology Press.

Heath, H., \& Cowley, S. (2004). Developing a grounded theory approach: A comparison of Glaser and Strauss. International Journal of Nursing Studies, 41, 141-150.

International AIDS Society. (2009). Evaluation report. 5 th IAS Conference on HIV Pathogenesis, Treatment and Prevention, July 19-22, 2009, Cape Town, South Africa. Retrieved December 4, 2011, from http://www. iasociety.org/Web/WebContent/File/IAS\% $202009 \% 20$ Evaluation\%20Report.pdf

Jago, L., \& Deery, M. (2010). Delivering innovation, knowledge and performance: The role of business events. Sydney: Business Events Council of Australia. Retrieved December
4, 2011, from http://www.businesseventscouncil.org.au/ files/Business_Events_Innovation_Report_Mar10.pdf

Jago, L., \& Deery, M. (2011). The holistic value of business events: Interim report_-May 2011. Melbourne: Melbourne Convention \& Visitors Bureau.

Joint Meetings Industry Council. (2008). Understanding the value of the meetings industry. Retrieved September 21, 2011, from http://www.themeetingsindustry.org/ storage/perspective-articles/Article_Understanding_ the Value 08.10.pdf

Mair, J., \& Jago, L. (2010). The development of a conceptual model of greening in the business events tourism sector. Journal of Sustainable Tourism, 18(1), 77-94.

Mertens, D. M. (2005). Research and evaluation in education and psychology: Integrating diversity with quantitative, qualitative, and mixed methods (2nd ed.). Thousand Oaks, CA: Sage.

Swarbrooke, J., \& Horner, S. (2001). Business travel and tourism. Oxford: Butterworth-Heinemann.

The Business Events Industry Strategy Group. (2008). National business events strategy for Australia 2020: The business of events-Australia's untapped potential. Retrieved December 4, 2011, from http://www. businesseventscouncil.org.au/files/BES\%20full\%20 doc\%20Nov08.pdf

Tourism Research Australia. (2009). Business events in Australia: Results from the international visitor survey and the national visitor survey 2008. Retrieved September 21, 2011, from http://www.ret.gov.au/tourism/Documents/ Business\%20Events\%20FINAL.pdf

Tourism Research Australia. (2010). Business events: Latest industry performance. Retrieved September 21, 2011, from http://www.ret.gov.au/tourism/Documents/ tra/Snapshots $\% 20$ and $\% 20$ Factsheets/Business $\% 20$ Events\%20Latest\%20Industry\%20Performance.pdf

Tourism Research Australia. (2012). Business event visitors: 2011. Retrieved May 16, 2012, from http://www.ret.gov.au/ tourism/Documents/tra/BusinessEventsVisitors2011.pdf

Veal, A. J. (2006). Research methods for leisure and tourism: A practical guide, (3rd ed.). Harlow, England: Pearson Education Ltd.

Wood, E. H. (2009). An impact evaluation framework: Local government community festivals, Event Management, 12(3-4), 171-85. 


\section{Event Management}

Title Details

Table of Contents

\begin{tabular}{|l|}
\hline Related Titles \\
\begin{tabular}{|l|} 
Alternative Media \\
Edition (1)
\end{tabular} \\
\hline Lists \\
\hline Marked Titles (0) \\
\hline Search History \\
\hline event management - \\
\hline
\end{tabular}

\begin{tabular}{|c|c|c|}
\hline Title & Event Management: an international journal & $+n$ \\
\hline ISSN & $1525-9951$ & \\
\hline Publisher & Cognizant Communication Corporation & MANAGEMENT \\
\hline Country & United States & rasines \\
\hline Status & Active & $=$ \\
\hline Start Year & 1993 & 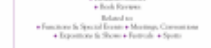 \\
\hline Frequency & Quarterly & 8. = \\
\hline Language of Text & Text in: English & \\
\hline Refereed & Yes & \\
\hline Abstracted / Indexed & Yes & \\
\hline Serial Type & J ournal & \\
\hline Content Type & Academic / Scholarly & \\
\hline Format & Print & \\
\hline Website & https://www.cognizantcommunication.com/jo & ent-management \\
\hline Description & $\begin{array}{l}\text { Publishes articles intended to meet the needs } \\
\text { with the business of special events for non-pr } \\
\text { carry out the missions and as a catalyst for cc }\end{array}$ & $\begin{array}{l}\text { profession. Deal } \\
\text { organizations to } \\
\text { lopment. }\end{array}$ \\
\hline \multicolumn{3}{|c|}{ Subject Classifications } \\
\hline \multicolumn{3}{|c|}{ Additional Title Details } \\
\hline \multicolumn{3}{|l|}{ Title History Details } \\
\hline \multicolumn{3}{|c|}{ Publisher \& Ordering Details } \\
\hline \multicolumn{3}{|l|}{ Price Data } \\
\hline \multicolumn{3}{|l|}{ Online Availability } \\
\hline \multicolumn{3}{|c|}{ Abstracting \& Indexing } \\
\hline \multicolumn{3}{|l|}{ Other Availability } \\
\hline \multicolumn{3}{|l|}{ Demographics } \\
\hline Reviews & & \\
\hline
\end{tabular}

